\title{
Catalymetric Analysis of Molybdenum (VI) by Means of an Iodide Ion-Selective Electrode
}

\author{
Masamitsu KATAOKA* and Tomihito KAMBARA*
}

\begin{abstract}
The oxidation of iodide ion to iodine by peroxoborate ion takes place in an acidic environment and is catalysed by $\mathrm{Mo}(\mathrm{VI})$. The reaction rate is determined by measuring the iodide ion concentration, which can easily be traced by the measurement of potential using an iodide ion-selective electrode. The rate is proportional to the concentration of catalyst and so it is possible to determine a microamuont of $\mathrm{Mo}$ (VI). The appropriate reaction condition was decided by the method of experimental design of three-sided classification; the most suitable concentrations of $\mathrm{NaBO}_{3}, \mathrm{KI}$ and $\mathrm{H}_{2} \mathrm{SO}_{4}$ are found to be $1 \mathrm{mM}, 40 \mu \mathrm{M}$ and $27 \mathrm{mM}$, respectively. The working curve with a good proportionality was obtained and by this method it is possible to determine $M \circ(\mathrm{VI})$ in the concentration range from 0.5 to $5.0 \mu \mathrm{M}$ in the reaction solution. Chromium(VI) shows a strong interference.
\end{abstract}

\section{Introduction}

Molybdate catalyses the oxidation of iodide to iodine by sodium peroxoborate in an acidic milieu. It was found that the rate of reaction is proportional to the molybdate concentration and can be used for the microdetermination of $\mathrm{Mo}(\mathrm{VI})$.

Wilson ${ }^{1)}$ described the catalymetric determination of molybdate by using a double-beam recording spectrophotometer with a pair of micro absorptiometric flow cells. Several kinetic methods of determining molybdate have been investigated by means of spectrophotometry ${ }^{2,3)}$, polarography ${ }^{4,5)}$, potentiostatic method with an automatic buret ${ }^{6)}$ and ion-selective electrode methods ${ }^{7,8)}$.

The present authors have reported the catalymetric analysis of molybdate and tungstate by the aid of an iodide ion-selective electrode in the reaction of hydrogen peroxide with potassium iodide in an acidic milieu ${ }^{7}$. In the present paper, the oxidation of iodide by peroxoborate is reported.

The net reaction on which the method is based is as follows.

$$
\mathrm{BO}_{3}^{-}+2 \mathrm{I}^{-}+2 \mathrm{H}^{+}=\mathrm{BO}_{2}^{-}+\mathrm{I}_{2}+\mathrm{H}_{2} \mathrm{O}
$$

The concentrations of peroxoborate and hydrogen ion are kept in a large excess in comparison with that of iodide, so that these concen-

\footnotetext{
* Department of Chemistry, Faculty of Science, Hokkaido University (Sapporo)
}

trations remain essentially constant during the reaction time. Under these conditions the reaction rate is proportional to the concentrations of molybdate and iodide ion as shown by

$$
-\frac{d\left[\mathrm{I}^{-}\right]}{d t}=k C_{\mathrm{K}}\left[\mathrm{I}^{-}\right]
$$

where $k$ is the rate constant, $C_{\mathrm{K}}$ the catalyst concentration, and $\left[\mathrm{I}^{-}\right]$the iodide ion concentration. Integration of eq. (2) yields

$$
\left[\mathrm{I}^{-}\right]=\left[\mathrm{I}^{-}\right]^{*} \exp \left(-k C_{\mathrm{K}} t\right)
$$

where $\left[\mathrm{I}^{-}\right]^{*}$ is the initial concentration of iodide ion. If the electrode is completely selective for iodide ion, the potential is shown by

$$
E=E_{0}-\frac{2.303 R T}{F} \log a_{1^{-}}
$$

where $E_{0}$ is a constant and $a_{\mathrm{I}^{-}}$is the activity of iodide ion. Combination of eqs. (3) and (4) indicates that the potential of the iodide ionselective electrode should become more positive during the reaction course and the potential change in unit time is proportional to the catalyzer concentration. Thus, it is possible to determine a trace amount of molybdate by the ion-selective electrode method.

\section{Experimental}

Potential measurement was carried out with a Toa $\mathrm{pH}$ meter model HM-7A with an iodide ion-selective electrode, type I-125, and a double junction calomel electrode, HC-305 DS, manu- 
factured by Toa Dempa Kogyo Co. The potential change was recorded on a Toa polyrecorder model EPR-3T. The test solution is thermostated at $25^{\circ} \mathrm{C}$.

Since sodium peroxoborate solution decomposes gradually at room temperature, always a freshly prepared $5.0 \times 10^{-2} \mathrm{M}$ solution was used. Ammonium molybdate solution is prepared by diluting the $10^{-2} \mathrm{M}$ stock solution. This solution is standardized by back-titration, in which the excess EDTA is titrated with standard copper (II) solution with PAN indicator. All the solutions are prepared with the water, once deionized and twice distilled.

In a $50 \mathrm{~cm}^{3}$ measuring flask is prepared a sodium peroxoborate solution to the mark and to the another flask are added potassium iodide, sulfuric acid solutions and the molybdate sample solution and then one dilutes the mixture to the mark with water. Each concentration of these reagents is so chosen that the desired final concentrations are attained after mixing of two $50 \mathrm{~cm}^{3}$ solutions. After the flask was thermostated, one transfers the solution containing iodide ion into a $250 \mathrm{~cm}^{3}$ beaker, and then inserts the iodide ion-selective electrode and calomel electrode in the beaker and stirs the solution. After several minutes when the potential of the pI-electrode has been stabilized, one adds the peroxoborate solution and at the same time begins to record the potential value.

\section{Results and Discussion}

The potential-time curve, which is recorded as mentioned above, is shown in Fig. 1. The reason why the potential changes rapidly at the beginning of the reaction may be attributed to the sudden decrease in iodide concentration caused by the addition of peroxoborate solution. The slope of the linear section of curve in Fig. 1 is obtained by the familiar method of

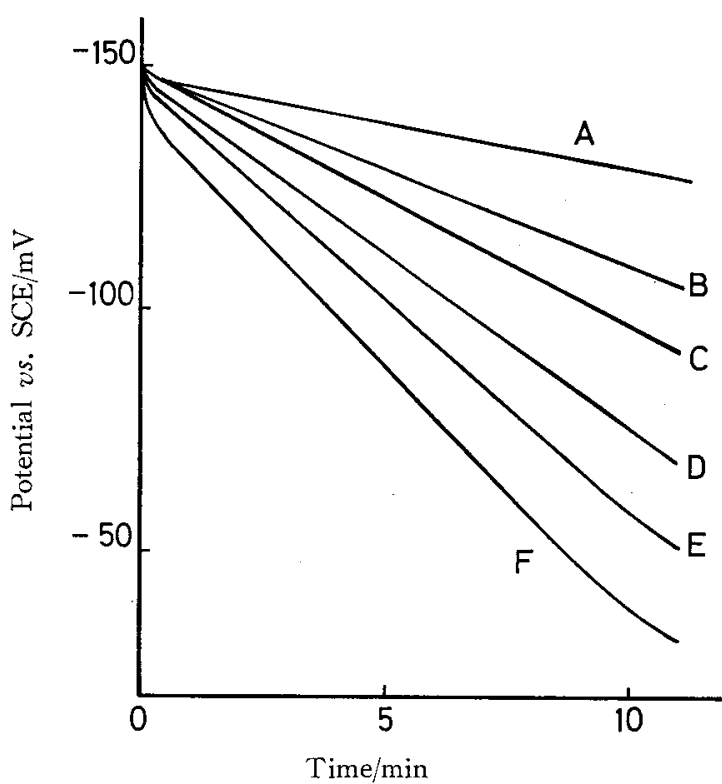

Fig. 1 Change of the potential of iodide ion-selective electrode with time

The composition of the reaction solution: $\left[\mathrm{NaBO}_{3}\right]=1 \mathrm{mM},[\mathrm{KI}]=40 \mu \mathrm{M},\left[\mathrm{H}_{2} \mathrm{SO}_{4}\right]=$ $27 \mathrm{mM}$. Mo(V) concentrations are: $\mathrm{A} 1$, B2, C3, D4, E5, F6, G7 M. Temp. $25^{\circ} \mathrm{C}$

linear regression. The most suitable concentrations of sodium peroxoborate, potassium iodide and sulfuric acid were determined by the experimental design". Each component, to which are affixed the mark $\mathrm{A}, \mathrm{B}$ and $\mathrm{C}$, respectively, is divided into three different levels of concentration. The allotment is shown in Table 1.

Table 1 Allotment of experimental conditions

\begin{tabular}{c|l|l|l|l}
\hline \hline Factor & Reagent & \multicolumn{3}{|c}{ Concentration } \\
\hline $\mathrm{A}$ & $\mathrm{NaBO}_{3}$ & $\mathrm{~A}_{1}=0.5 \mathrm{mM}$ & $\mathrm{A}_{2}=1 \mathrm{mM}$ & $\mathrm{A}_{3}=1.5 \mathrm{mM}$ \\
$\mathrm{B}$ & $\mathrm{KI}$ & $\mathrm{B}_{1}=20 \mu \mathrm{M}$ & $\mathrm{B}_{2}=40 \mu \mathrm{M}$ & $\mathrm{B}_{3}=60 \mu \mathrm{M}$ \\
$\mathrm{C}$ & $\mathrm{H}_{2} \mathrm{SO}_{4}$ & $\mathrm{C}_{1}=17.9 \mathrm{mM}$ & $\mathrm{C}_{2}=27 \mathrm{mM}$ & $\mathrm{C}_{3}=36 \mathrm{mM}$ \\
\hline
\end{tabular}

Table 2 Rate of potential change in $\mathrm{mV} \mathrm{min}^{-1}$ obtained by the three-sided classification

\begin{tabular}{c|c|c|c|c|c|c|c|c|c}
\hline \hline \multicolumn{9}{c|}{$\mathrm{A}_{\mathrm{i}}$} & \multicolumn{3}{c|}{$\mathrm{A}_{2}$} & \multicolumn{3}{c}{$\mathrm{A}_{3}$} \\
\hline & $\mathrm{B}_{1}$ & $\mathrm{~B}_{2}$ & $\mathrm{~B}_{3}$ & $\mathrm{~B}_{1}$ & $\mathrm{~B}_{2}$ & $\mathrm{~B}_{3}$ & $\mathrm{~B}_{1}$ & $\mathrm{~B}_{2}$ & $\mathrm{~B}_{3}$ \\
\hline $\mathrm{C}_{1}$ & 4.720 & 5.293 & 4.867 & 4.693 & 5.280 & 5.927 & 5.665 & 5.340 & 4.960 \\
$\mathrm{C}_{2}$ & 5.373 & 5.500 & 6.530 & 4.887 & 7.093 & 5.633 & 6.016 & 5.387 & 5.947 \\
$\mathrm{C}_{3}$ & 5.387 & 5.897 & 5.487 & 5.527 & $\mathbf{5 . 7 5 3}$ & 6.188 & 5.280 & 5.947 & 6.637 \\
\hline
\end{tabular}


The order of 27 experiments is arranged at random by the aid of a table of random numbers. The rate of potential change is summarized in Table 2.

The results of the analysis of variances with three-sided classification are shown in Table 3 . All the values of $F_{0}$ about the concentrations

Table 3 Analysis of variances applied to the data shown in Table 2

\begin{tabular}{|c|c|c|c|c|c|}
\hline $\begin{array}{l}\overline{\text { Dis- }} \\
\text { persion }\end{array}$ & $S$ & $\phi$ & $V$ & $F_{0}$ & $F$ \\
\hline $\bar{A}$ & 3.062 & 2 & 1.531 & 0.3495 & $F(2,8,0.05)=4.46$ \\
\hline B & 13.862 & 2 & 6.931 & 1.5821 & " \\
\hline $\mathrm{C}$ & 22.360 & 2 & 11.180 & 2.5821 & $" 1$ \\
\hline $\mathrm{A} \times \mathrm{B}$ & 9.343 & 4 & 2.336 & 0.5332 & $F(4,8,0.05)=3.48$ \\
\hline $\mathrm{B} \times \mathrm{C}$ & 2.171 & 4 & 0.543 & 0.1239 & " \\
\hline $\mathrm{A} \times \mathrm{C}$ & 1.578 & 4 & 0.395 & 0.0902 & $" 1$ \\
\hline $\mathrm{E}$ & 35.045 & 8 & 4.381 & - & - \\
\hline Total & 87.421 & 26 & & & \\
\hline
\end{tabular}

$S:$ sum of squares, $\phi:$ degree of freedom, $V:$ variance, $F_{0}$ : ratio of variances, $F$ : value of $F$-distribution. In every case $F>F_{0}$

of sodium peroxoborate, potassium iodide and sulfuric acid are smaller than the value of $F$ $(2,8,0.05)$ in the table. From the results, it is seen that there are no significant difference in the reaction rates with the various concentrations of the above three reaction participants and no interaction between these components. Thus, we have determined that the most suitable condition is the combination of factors $A_{2}, B_{2}$ and $\mathrm{C}_{2}$ in Table 1 .

The established procedures of catalymetric determination of molybdate and the detection limits hitherto reported are tabulated in Table 4. It should be noted that in the present method the concentration of potassium iodide is much lower than the other methods. The working curve for the present method is given in Fig. 2. In the molybdate concentration range

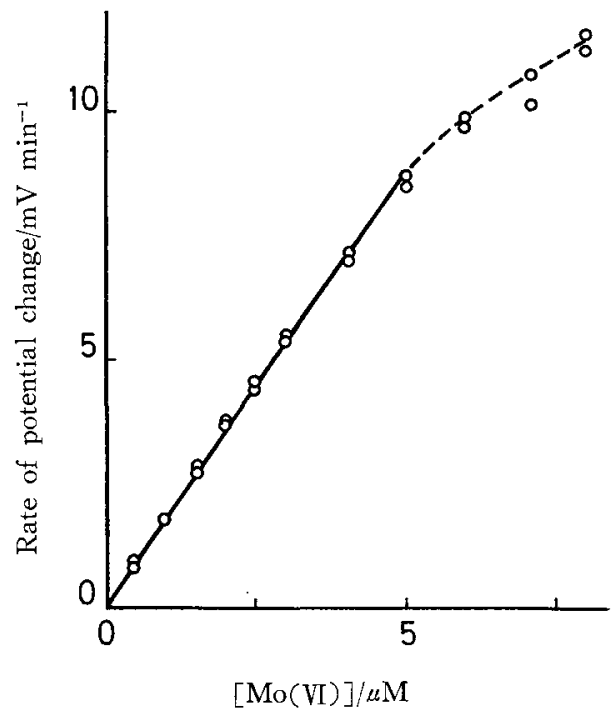

Fig. 2 Calibration curve for $\mathrm{Mo}(\mathrm{Vl})$

The composition of the reaction solution is the same as in Fig. 1. The curve is expressed by $Y=(1.7173 \pm 0.0033) C_{\mathrm{K}}+(0.1484 \pm 0.0219)$ where, $Y$ is expressed in $\mathrm{mV} \mathrm{min}^{-1}$ and $C_{\mathrm{K}}$ is the concentration of $\mathrm{Mo}(\mathrm{VI})$ in $\mu \mathrm{M}$. Correlation coef.: 0.9974

of 0.5 to $5 \mu \mathrm{M}$, the rate of potential change is proportional to the concentration. If one mixes twe solutions, it is inevitable that some time elapses until the complete homogeneity is attained. Thus, when man traces the absorbance of the iodine produced, it is difficult to define the reaction time exactly. It is an essential merit of the present pI-electrode

Table 4 Comparison of the compositions of reaction solutions for the catalymetric determination of $\mathrm{Mo}(\mathrm{VI})$

\begin{tabular}{|c|c|c|c|c|c|c|}
\hline Component & $\begin{array}{l}\text { Present } \\
\text { method }\end{array}$ & $\begin{array}{l}\text { Iodide ion- } \\
\text { selective } \\
\text { elecrtode? }^{7}\end{array}$ & Photometry ${ }^{1)}$ & Photometry ${ }^{3)}$ & Potentiostat ${ }^{6)}$ & Polarography ${ }^{5}$ \\
\hline $\mathrm{NaBO}_{3}$ & $1 \mathrm{mM}$ & - & $5 \mathrm{mM}$ & - & - & - \\
\hline $\mathrm{H}_{2} \mathrm{O}_{2}$ & - & $5 \mathrm{mM}$ & & $1 \mathrm{mM}$ & $6 \mathrm{mM}$ & $4.87 \mathrm{mM}$ \\
\hline $\mathrm{KI}$ & $40 \mu \mathrm{M}$ & $1 \mathrm{mM}$ & $60 \mathrm{mM}$ & $2 \mathrm{mM}$ & $5 \mathrm{mM}$ & $0.4 \mathrm{mM}$ \\
\hline $\mathrm{H}_{2} \mathrm{SO}_{4}$ & $27 \mathrm{mM}$ & $200 \mathrm{mM}$ & - & $80 \mathrm{mM}$ & $8 \mathrm{mM}$ & $80 \mathrm{mM}$ \\
\hline $\begin{array}{l}\text { Detection limit, } \\
\mu \mathrm{g} / \mathrm{cm}^{3}\end{array}$ & 0.09 & 0.22 & 0.1 & 0.02 & 0.06 & 0.467 \\
\hline Other component & - & - & $\begin{array}{l}\text { acetate buffer } \\
\text { pH } 5.6\end{array}$ & - & $\mathrm{I}_{2}$ & $\begin{array}{l}0.06 \% \\
\text { gelatin }\end{array}$ \\
\hline
\end{tabular}


method that the potential becomes to change linearly with time thirty seconds after mixing, as Fig. 1 shows.

Since several metal ions also catalyze the reaction, interferences by some diverse ions are tested and the results are summarized in Table 5. The composition of the reaction solution is

Table 5 Effect of interfering ions

\begin{tabular}{l|c|c|c|c}
\hline \multirow{2}{*}{ Ion } & \multicolumn{4}{|c}{ Concentration } \\
\cline { 2 - 5 } & $3 \mu \mathrm{M}$ & $30 \mu \mathrm{M}$ & $0.3 \mathrm{mM}$ & $3 \mathrm{mM}$ \\
\hline $\mathrm{Cu}($ II $)$ & - & - & - & + \\
$\mathrm{Fe}(\mathrm{II})$ & - & - & + & + \\
$\mathrm{Zn}(\mathrm{II})$ & - & - & - & - \\
$\mathrm{Mn}$ (II) & - & - & + & + \\
$\mathrm{V}(\mathrm{V})$ & - & + & + & + \\
$\mathrm{Zr}(\mathrm{VI})$ & - & - & + & + \\
$\mathrm{Cr}(\mathrm{VI})$ & + & + & + & + \\
$\mathrm{W}(\mathrm{VI})$ & - & + & + & + \\
\hline
\end{tabular}

The composition of the reaction solution is the same as in Fig. 1 , and $[\mathrm{Mo}(\mathrm{VI})]$ is kept to $3 \mu \mathrm{M}$. Plus sign implies interference. the same as above, and the molybdate concentration is kept to $3 \mu \mathrm{M}$. The familiar $F$ - and $t$-tests were used to determine the degree of interference. Among these metal ions, chromium (VI) interferes seriously, and also tungstate (VI) and vanadate (V) catalyse the reaction. $<$ E504> (Received May 13, 1977)

\section{References :}

1) A.M. Wilson, Anal. Chem. 38, 1784 (1966).

2) K.B. Yatsimirskii, L.P. Afanaseva, Zh. Anal. Khim. 11, 319 (1956)

3) K.B. Yatsimirskii, "Kinetic Methods of Analysis", (1966), Pergamon Press, Oxford.

4) G.P. Haight, Jr., Anal. Chem. 32, 1505 (1951).

5) T. Kambara, N. Tanaka, K. Fukada, Bunseki Kagaku 17, 1144 (1968).

6) H. Weisz, D. Klockow, H. Ludwig, Talanta 16, 921 (1969).

7) M. Kataoka, T. Kambara, Bunseki Kiki 10, 773 (1972).

8) M. Kataoka, T. Kambara, Bunseki Kagaku 23, 1157 (1974).

9) V.V. Nalimov, "The Application of Mathematical Statistics to Chemical Analysis", p. 154 (1963), Pergamon Press, Oxford.

\section{失敗の記録も発表を}

集積回路で電着錫の“ひげ状自然生長”が回路障害を起し困っている．Zakraysek はこの生長原因は電解条 件，添加剂による電着応力によるもので，電着物を化学的，機械的な処理，たとえば，硫酸浴への浸せき，熱 処理，エヤージェットクリーニングなどによって結晶核を除けげ，ウィスカーの発生を抑制することができる ことを述べている.

失敗研究の記録や，自社の欠陷製品の原因解明結果などは場合によっては社命にかかわるので公表しにくい ことが多い，腐食事例の公表などもこの部類であろう．しかし技術の向上，発展のためこれらは前車の蹾で貴 重なデーターである．勇気を出して大きな視野からぜひ発表していただきたい，単化研究発展のためだけでな く大切な資源の保護や，上きには人命にもつながることがあるから。

文献 L. Zakraysek, Plating and Surface Finishing 64, 38, March (1977). (T.M.) 